\title{
Value Addition in Beverages with Papaya Leaves Extract (Carica Papaya)
}

\author{
Sharma Megha ${ }^{1}$, Gupta Alka ${ }^{2}$ \\ ${ }^{1}$ Research Scholar, Foods and Nutrition, Ethelind School of Home Science, , SHIATS Allahabad - 211007 \\ ${ }^{2}$ Assistant Professor, Foods and Nutrition, Ethelind School of Home Science, SHIATS Allahabad - 211007
}

\begin{abstract}
Various parts of papaya leaves extract have been traditionally used as ethno medicine for a number of disorders, including different diseases. The present study was carried out "Value addition in beverages with papaya leaves extract (Carica papaya)" with the objectives to determine the nutritive value of different beverages by the incorporation of papaya leaves extract at different levels and to assess the Organoleptic evaluation of the prepared beverages, banana shake, mosambi juice pineapple juice and pomegranate juice. Nutritional composition of prepared beverages were analyzed by AOAC.(2007)The nutrient dense products can be helpful from therapeutic point of view for those people suffering from dengue, liver problems, stomach problems, and stone formation and other iron deficiencies diseases. Carica papaya leaves extract mainly effects on dengue fever. Dengue fever is one of the life threatening disease caused by dengue virus(flavivirus).so far there is no effective medicine and vaccine approved for dengue fever. The effect of papaya leaf juice improved the health of patient by increasing the number of platelets. The result also indicated that the leaf and pulp extract increases the formation of the thrombocytes, especially at $300 \mathrm{mg} \mathrm{kg}^{-1}$ out of the three extract, the pulp extract boosted the thrombocytes number more in order, pulp extract>leaf extract>seed extract.
\end{abstract}

Keywords: Papaya Leaves, Nutritional Composition, Sensory Evaluation

\section{Introduction}

Numerous studies have demonstrated that beverages containing different micronutrients (Wolf 2008) ${ }^{16}$ Historically, fruit juice was recommended by pediatricians as a source of vitamin $\mathrm{C}$ and an extra source of water for healthy infants and young children as their diets expanded to include solid foods with higher renal solute. The pattern of fruit juice consumption has changed over time. While fruit juice is a healthy, low-fat, nutritious beverage.(Coll 1996) ${ }^{3}$.World over, at least 35,000 plant species are used for medicinal purpose (Ikpeme 2011) ${ }^{5}$. Carica papaya, believed to be originated in Central America, is a plant that belongs to the family caricaceaes (Zakaria et.al 2006) ${ }^{17}$.

The leaves of papaya have been shown to contain many active components that can increase the total antioxidant powder in blood and reduce lipid per oxidation level, such as papain, chymopapain cystatin, $\alpha$ tocopherol, ascorbic acid, flavonoids, gynogenic glycosides and glucosinotes.Carica papaya leaves juice is consumed for its purported anti-cancer activity by people living on the gold coast of Australia .Carica papaya leaf juice have also been used for a long time as an aboriginal remedy for various disorders, including cancer and infectious disease (Otsuki 2009) ${ }^{10}$.The dengue fever is one of the threatening disease caused by dengue virus (Flavirus) that is borne and transmitted by mosquitoes living in tropical and subtropical climates worldwide, mostly in urban and semi urban areas. As per the estimation of World Health Organization, every year, 50 million peoples access the world are infected by dengue and about $2 / 5$ of the world population ( 2.5 billion peoples) are at risk from this dreadful disease, which spread over about 100 countries. Dengue is also known as breakbone fever as it causes extreme body pain, especially in the joints of bones. There have no effective medicine and vaccine approved for the dengue virus and developing a safe and effective antiviral drug is difficult, because viruses use the host's cells to replicate. This makes it difficult to eradicate the virus without harming the host organism's cells. (Kala 2012) ${ }^{7}$.

\section{Materials and Method}

The present investigation was carried out in the Research Laboratory of Foods and Nutrition,Ethelind School of Home Science, (SHIATS), Allahabad. Healthy green leaves of Papaya (Carica papaya) required for the experiments were collected from the farm of SHIATS, Allahabad .Only the fresh leaves were collected. These leaves were washed with the help of clean water so as to remove the dirt and other disease causing organism

\section{Preparation of Papaya Leaves Extract:}

Wash and partly dry several medium-size 5 papaya leaves (To remove microorganism and dirt)

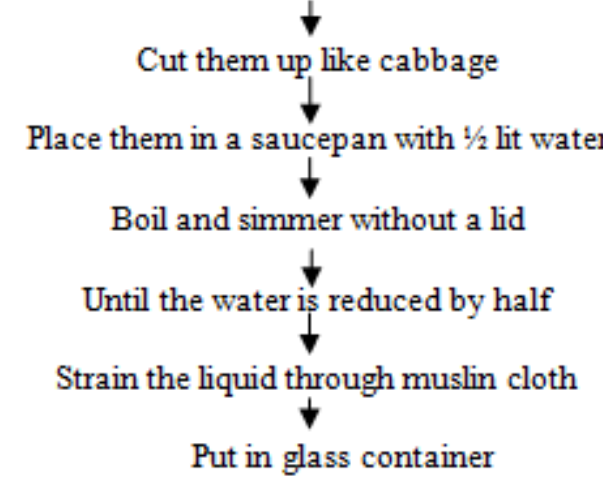

Flow diagram for extract of papaya leaves

Formulation and preparation of beverages

Value added beverages utilizing papaya leaves were prepared keeping in mind the food habits in the niche area as well as border areas adjoining the production catchment. In 


\section{International Journal of Science and Research (IJSR) \\ ISSN (Online): 2319-7064 \\ Index Copernicus Value (2015): 78.96 | Impact Factor (2015): 6.391}

order to select the ratios of ingredients, several beverages namely Banana shake, Mosambi juice, Pineapple juice and Pomegranate juice, were prepared with the incorporation of fresh papaya leaves extract. Three different treatments coded as $\mathrm{T}_{0}$ (control without papaya leaves extract), $\mathrm{T}_{1}$ (5\% of papaya leaves extract), $\mathrm{T}_{2}$ (10\% of papaya leaves extract) and $\mathrm{T}_{3}$ (15\% of papaya leaves extract) were selected for the study. To perform sensory evaluation judge were drown from the group of faculty and $\mathrm{PhD}$ scholars of Ethelind school of Home Science, SHIATS.The judge were trained and given pre-prepared tips for each of the beverages and subjective measurements feelings. Sensory attributes i.e. color and appearance, consistency, tastes and flavors and all acceptability of the prepared products by using nine points Hedonic scale (9-like extremely and 1-dislike extremely)in order to determine the nutritional characteristics of these, standard methods described below as follows-:

\section{Proximate Composition}

The moisture, crude protein and ash content were determined by standard procedures of AOAC (2007).Carbohydrate content was calculated by difference and energy content by multiplying protein, fat and carbohydrate by factors 4,9 and 4 respectively.

\section{Minerals and Vitamin Analysis}

For iron and calcium content, ash solution were prepared after dry ashing of the samples using standard methods (AOAC, 2007) ${ }^{1}$.The vitamin $\mathrm{C}$ was determined using, AOAC (2007) ${ }^{1}$. Method and total carotene content was determined using methods of Rangana, (2001) $)^{\mathbf{1 2}}$. All determinations were done in triplicate.

\section{Statistical analysis}

The data obtained from sensory evaluation were statistically analyzed by using analysis of variance technique (one way classification). Significant difference between the treatments was determined by using $\mathrm{CD}$ (critical difference) test.

\section{Results and Discussion}

The products were standardized and were subjected to Organoleptic evaluation within one hour of preparation which was considered as zero days. The result of the evaluation carried out revealed that one hundred percent of the persons their willingness to prepare the products at home. Papaya leaves is nutritionally superior compared to other leaves.

\section{Banana Shake}

As evident from table 1, banana shake prepared from papaya leaves extract were given high scores ranging from (7.45 to 8.24), All experimental recepies were accepted in terms of appearance, colour, texture and overall acceptability. Present result of stastical analysis of patability evaluation scoring using ANOVA. Irrespective of the type of papaya leaves extract, accepted for the appearance and colour, significant difference were noted in texture, taste and flavor of papaya leaves extract beverages compared to the control. Result of overall acceptability of beverages indicates was highly comparable to the control as also evident from the insignificant difference between the scores $\mathrm{T}_{1}$ was found the best product to analysis with the incorporation of $5 \%$ of papaya leaves extract. One can improve the taste profile of banana shake by using extract of papaya leave.

Table 1: The average sensory scores of different parameters in control and treated sample of 'Banana shake'.

\begin{tabular}{|c|c|c|c|c|}
\hline \multirow{2}{*}{$\begin{array}{c}\text { Sensory } \\
\text { Characteristic } \\
\text { /Treatments }\end{array}$} & \multicolumn{4}{|c|}{ Scores on 9 point hedonic scale } \\
\hline & $\begin{array}{l}\text { Colour and } \\
\text { appearance }\end{array}$ & Texture & $\begin{array}{c}\text { Taste and } \\
\text { flavour }\end{array}$ & $\begin{array}{c}\text { Overall } \\
\text { acceptability }\end{array}$ \\
\hline $\mathrm{T}_{0}($ Control $)$ & $8.66 \pm 0.23$ & $8 \pm 0.16$ & $8.8 \pm 0.08$ & $8.4 \pm 0.13$ \\
\hline $\mathrm{T}_{1}$ & $8.73 \pm 0.15$ & $7.8 \pm 0.12$ & $8.66 \pm 1.0$ & $8.24 \pm 0.05$ \\
\hline $\mathrm{T}_{2}$ & $8.4 \pm 0.24$ & $7.6 \pm 0.58$ & $8.13 \pm 0.15$ & $8.08 \pm 0.12$ \\
\hline $\mathrm{T}_{3}$ & $7.46 \pm 0.23$ & $7.2 \pm 0.16$ & $7.4 \pm 0.28$ & $7.45 \pm 0.19$ \\
\hline $\mathrm{F} \%$ & $11.59(\mathrm{~S})$ & $4(\mathrm{NS})$ & $26.41(\mathrm{~S})$ & $40(\mathrm{~S})$ \\
\hline C.D & 0.13 & - & 0.25 & 1.17 \\
\hline
\end{tabular}

\section{Mosambi Juice}

Table. 2 shows that result the sensory evaluation of mosambi juice prepared from papaya leave extract shows that in contrast to banana shake, Mosambi juice were highly acceptable and very close to all sensory characteristics followed by mosambi juice from papaya leave extract. Scores ranging from 7.70 to 8.08.Results of ANOVA reflected that irrespective of the type of papaya leave extract, mosambi juice shows significant difference when compared with control for appearance, colour, texture and overall acceptability.

Table 2: The average sensory scores of different parameters in control and treated sample of 'Mosambi juice'.

\begin{tabular}{|c|c|c|c|c|}
\hline $\begin{array}{c}\text { Sensory } \\
\text { Characteristic/ } \\
\text { Treatments }\end{array}$ & \multicolumn{4}{|c|}{ Scores on 9 point hedonic scale } \\
\cline { 2 - 5 } & $\begin{array}{c}\text { Colour and } \\
\text { appearance }\end{array}$ & Consistency & $\begin{array}{c}\text { Taste and } \\
\text { flavour }\end{array}$ & $\begin{array}{c}\text { Overall } \\
\text { acceptability }\end{array}$ \\
\hline $\mathrm{T}_{0}($ Control) & $8.33 \pm 0.25$ & $8 \pm 0.16$ & $8.33 \pm 0.15$ & $8.10 \pm 0.25$ \\
\hline $\mathrm{T}_{1}$ & $8.13 \pm 0.07$ & $7.13 \pm 0.03$ & $8.53 \pm 0.40$ & $8.08 \pm 0.21$ \\
\hline $\mathrm{T}_{2}$ & $7.93 \pm 0.25$ & $7.66 \pm 0.19$ & $7.93 \pm 0.25$ & $7.81 \pm 0.24$ \\
\hline $\mathrm{T}_{3}$ & $7.53 \pm 0.16$ & $7.2 \pm 0.16$ & $7.13 \pm 0.03$ & $7.70 \pm 0.17$ \\
\hline $\mathrm{F} \%$ & $21.87(\mathrm{~S})$ & $4(\mathrm{NS})$ & $10.45(\mathrm{~S})$ & $2.39(\mathrm{NS})$ \\
\hline $\mathrm{C} . \mathrm{D}$ & 0.13 & - & 0.36 & \\
\hline
\end{tabular}

\section{Pineapple Juice}

Table. 3 shows that mean score for sensory evaluation of control and experimental pineapple juice showed no obvious differences between pineapple juice prepared by incorporating papaya leave extract for appearance of colour and texture. Pineapple juice high ranging from 7.55 to 8.48 .

Table 3: The average sensory scores of different parameters in control and treated sample of 'Pineapple juice'.

\begin{tabular}{|c|c|c|c|c|}
\hline \multirow{2}{*}{$\begin{array}{c}\text { Sensory } \\
\text { Characteristic/ } \\
\text { Treatments }\end{array}$} & \multicolumn{4}{|c|}{ Scores on 9 point hedonic scale } \\
\cline { 2 - 5 } & $\begin{array}{c}\text { Colour and } \\
\text { appearance }\end{array}$ & Texture & $\begin{array}{c}\text { Taste and } \\
\text { flavour }\end{array}$ & $\begin{array}{c}\text { Overall } \\
\text { acceptability }\end{array}$ \\
\hline $\mathrm{T}_{0}($ Control $)$ & $8.66 \pm 0.21$ & $7.93 \pm 0.13$ & $8.8 \pm 0.08$ & $8.45 \pm 0.19$ \\
\hline $\mathrm{T}_{1}$ & $8.73 \pm 0.26$ & $8.2 \pm 0.24$ & $8.86 \pm 0.20$ & $8.48 \pm 0.61$ \\
\hline $\mathrm{T}_{2}$ & $8.4 \pm 0.24$ & $7.46 \pm 0.25$ & $8.13 \pm 0.15$ & $7.97 \pm 0.08$ \\
\hline $\mathrm{T}_{3}$ & $7.46 \pm 0.23$ & $7.8 \pm 0.08$ & $7.4 \pm 0.16$ & $7.55 \pm 0.49$ \\
\hline $\mathrm{F} \%$ & $11.59(\mathrm{~S})$ & $3.55(\mathrm{NS})$ & $26.41(\mathrm{~S})$ & $1.02(\mathrm{~N})$ \\
\hline $\mathrm{C} . \mathrm{D}$ & 0.31 & - & 0.24 & - \\
\hline
\end{tabular}

\section{Pomegranate Juice}

Table. 4 shows that pomegranate juice prepared from papaya leave extract were closely acceptable when compared with control for all sensory characteristics. Statistical interpretation for acceptability of experimental beverages

\section{Volume 6 Issue 7, July 2017 www.ijsr.net}




\section{International Journal of Science and Research (IJSR) \\ ISSN (Online): 2319-7064 \\ Index Copernicus Value (2015): 78.96 | Impact Factor (2015): 6.391}

revealed that papaya leave extract can be successfully incorporated in pomegranate juice high score ranging from 7.45 to 8.24 .

Table 4: The average sensory scores of different parameters in control and treated sample of 'Pomegranate juice'

\begin{tabular}{|c|c|c|c|c|}
\hline $\begin{array}{c}\text { Sensory } \\
\text { Characteristic/ } \\
\text { Treatments }\end{array}$ & \multicolumn{4}{|c|}{ Scores on 9 point hedonic scale } \\
\cline { 2 - 5 } & $\begin{array}{c}\text { Colour and } \\
\text { appearance }\end{array}$ & Texture & $\begin{array}{c}\text { Taste and } \\
\text { flavour }\end{array}$ & $\begin{array}{c}\text { Overall } \\
\text { acceptability }\end{array}$ \\
\hline $\mathrm{T}_{0}($ Control $)$ & $8.33 \pm 0.25$ & $7.8 \pm 0.16$ & $8.86 \pm 0.23$ & $8.41 \pm 0.15$ \\
\hline $\mathrm{T}_{1}$ & $8.13 \pm 0.19$ & $7.53 \pm 0.19$ & $8.66 \pm 0.20$ & $8.24 \pm 0.05$ \\
\hline $\mathrm{T}_{2}$ & $7.93 \pm 0.25$ & $7.93 \pm 0.19$ & $7.93 \pm 0.17$ & $8.03 \pm 0.53$ \\
\hline $\mathrm{T}_{3}$ & $7.53 \pm 0.11$ & $7.46 \pm 0.23$ & $7.4 \pm 0.16$ & $7.45 \pm 0.19$ \\
\hline $\mathrm{F} \%$ & $9.72(\mathrm{~S})$ & $1.86(\mathrm{NS})$ & $21.87(\mathrm{~S})$ & $40(\mathrm{~S})$ \\
\hline C.D & 0.12 & - & 0.13 & 0.12 \\
\hline
\end{tabular}

\section{Nutritional Composition of Prepared Beverages}

Table.5 shows that the wide ranges of variation were observed in the nutrient content of the beverages blending of papaya leaves extract with juices to enhance the composition of beverages. Present information regarding the mean nutrient composition of papaya leaves extract incorporated beverages (per $100 \mathrm{gm}$ ). Differences were observed between control and experimental beverages for their moisture, ash, energy, carbohydrate, protein, calcium, vitamin $\mathrm{C}$, iron, and total carotene of all four beverages prepared from papaya leave extract were found to be very good. Results showed that the moisture content was highest in pomegranate juice $(8.38 \pm 0.29 \mathrm{~g} / 100 \mathrm{~g})$. Ash content of Mosambi juice was observed to be maximum $(0.70 \pm 0.19 \mathrm{~g} / 100 \mathrm{~g})$ not only due to the basic ingredients but also due to incorporation of papaya leaves extract. Protein content of the sample was highest in banana shake $(3.38 \pm 0.28 \mathrm{~g} / 100 \mathrm{~g})$ followed by pomegranate juice $(2.70 \pm 0.21 \mathrm{~g} / 100 \mathrm{~g})$.Calcium content of the sample was found highest in banana shake $(147.33 \pm 0.83 \mathrm{mg} / 100 \mathrm{~g})$ and least by $(45.02 \pm 0.35 \mathrm{mg} / 100 \mathrm{~g})$. Iron content of the sample was observed highest in pomegranate juice $(4.49 \pm 0.51 \mathrm{mg} / 100 \mathrm{~g})$. Vitamin C content of the sample was highest in Mosambi juice $(62.27 \pm 0.32 \mathrm{mg} / 100 \mathrm{~g})$ and least by banana shake $(18.17 \pm 0.29 \mathrm{mg} / 100 \mathrm{~g})$. Carbohydrate content of the sample was highest in pineapple juice $(99.10 \pm$ $1.11 \mathrm{~g} / 100 \mathrm{~g})$. Energy content of the sample was highest in pomegranate juice $(7.81 \pm 0.29 \mathrm{kcal} / 100 \mathrm{~g})$ and least by pineapple juice $(4.09 \pm 0.27 \mathrm{kcal} / 100 \mathrm{~g})$. Total Carotene was found highest in pineapple juice $(644.50 \pm 3.21 \mathrm{mg} / 100 \mathrm{~g})$ followed by mosambi juice $(640.91 \pm 3.21 \mathrm{mg} / 100 \mathrm{~g})$. Besides papaya leave has many medicinal values, nutrient density can be increased by increasing the proportion of papaya leave extract in beverages.

Table 5: Mean nutrient composition of value added products developed by incorporating papaya leaves extract (per $100 \mathrm{ml}$ )

\begin{tabular}{|c|c|c|c|c|c|c|c|c|c|c|}
\hline Names & Treatments & $\begin{array}{c}\text { Moisture } \\
(\%)\end{array}$ & $\begin{array}{l}\text { Ash } \\
(g)\end{array}$ & $\begin{array}{l}\text { Protein } \\
(\mathrm{g})\end{array}$ & $\begin{array}{c}\text { Carbohydrate } \\
(g)\end{array}$ & $\begin{array}{l}\text { Energy } \\
\text { (Kcal) }\end{array}$ & $\begin{array}{l}\text { Calcium } \\
(\mathrm{mg})\end{array}$ & $\begin{array}{l}\text { Iron } \\
(m g)\end{array}$ & $\begin{array}{c}\text { Vitamin } \\
(\mathrm{mg})\end{array}$ & $\begin{array}{c}\text { Total } \\
\text { carotene } \\
(\mathrm{mg})\end{array}$ \\
\hline \multirow{4}{*}{$\begin{array}{c}\text { Banana } \\
\text { shake }\end{array}$} & $T_{0}$ & $7.51 \pm 0.36$ & $0.19 \pm 0.14$ & $2.93 \pm 0.17$ & $88.36 \pm 0.11$ & $3.67 \pm 0.39$ & $113 . \pm 0.20$ & $0.28 \pm 0.10$ & $4.15 \pm 0.41$ & $62.6 \pm 2.66$ \\
\hline & $T_{1}$ & $7.52 \pm 0.20$ & $0.20 \pm 0.14$ & $3.33 \pm 0.24$ & $88.65 \pm 0.12$ & $3.68 \pm 0.23$ & $139.93 \pm 0.60$ & $0.30 \pm 0.11$ & $17.14 \pm 0.18$ & $608.6 \pm 3.09$ \\
\hline & $T_{2}$ & $7.54 \pm 0.23$ & $0.40 \pm 0.22$ & $3.35 \pm 0.26$ & $92.66 \pm 10.17$ & $7.67 \pm 0.24$ & $145.33 \pm 0.81$ & $0.40 \pm 0.11$ & $18.13 \pm 0.19$ & $611.7 \pm 3.11$ \\
\hline & $T_{3}$ & $7.56 \pm 0.24$ & $0.60 \pm 0.18$ & $3.38 \pm 0.28$ & $92.68 \pm 0.19$ & $7.69 \pm 0.27$ & $147.33 \pm 0.83$ & $0.70 \pm 0.13$ & $18.17 \pm 0.29$ & $614.01 \pm 3.12$ \\
\hline \multirow{4}{*}{$\begin{array}{c}\text { Mosambi } \\
\text { juice }\end{array}$} & $T_{0}$ & $7.38 \pm 0.20$ & $0.47 \pm 0.14$ & $1.39 \pm 0.21$ & $56.23 \pm 00.20$ & $3.90 \pm 0.10$ & $66.01 . \pm 0.21$ & $1.47 \pm 0.27$ & $57.2 \pm 0.22$ & $88.40 \pm 0.23$ \\
\hline & $T_{1}$ & $7.40 \pm 0.22$ & $0.48 \pm 0.16$ & $1.42 \pm 0.24$ & $56.25 \pm 0.22$ & $3.92 \pm 0.12$ & $70.02 \pm 0.23$ & $1.33 \pm 0.24$ & $58.2 \pm 0.23$ & $634.90 \pm 3.15$ \\
\hline & $T_{2}$ & $7.60 \pm 0.24$ & $0.50 \pm 0.18$ & $1.45 \pm 0.25$ & $61.22 \pm 0.25$ & $4.01 \pm 0.24$ & $78.02 \pm 0.25$ & $1.43 \pm 0.25$ & $59.25 \pm 0.29$ & $637.9 \pm 3.19$ \\
\hline & $T_{3}$ & $7.90 \pm 0.26$ & $0.70 \pm 0.19$ & $1.47 \pm 0.26$ & $61.24 \pm 0.27$ & $4.09 \pm 0.27$ & $85.01 \pm 0.56$ & $1.47 \pm 0.27$ & $62.27 \pm 0.32$ & $640.91 \pm 3.21$ \\
\hline \multirow{4}{*}{$\begin{array}{l}\text { Pineapple } \\
\text { juice }\end{array}$} & $T_{0}$ & $8.29 \pm 0.22$ & $0.32 \pm 0.11$ & $1.51 \pm 0.11$ & $89.72 \pm 1.01$ & $3.65 \pm 0.21$ & $45.20 . \pm 0.19$ & $0.96 \pm 0.23$ & $45.60 \pm 1.20$ & $88.40 \pm 0.90$ \\
\hline & $T_{1}$ & $8.30 \pm 0.23$ & $0.35 \pm 0.14$ & $1.53 \pm 0.12$ & $92.02 \pm 1.05$ & $3.92 \pm 0.12$ & $50.2 \pm 0.23$ & $0.98 \pm 0.24$ & $48.60 \pm 1.70$ & $637.30 \pm 3.12$ \\
\hline & $T_{2}$ & $8.50 \pm 0.27$ & $0.39 \pm 0.16$ & $1.56 \pm 0.14$ & $97.74 \pm 1.09$ & $4.01 \pm 0.24$ & $56.21 \pm 0.25$ & $0.99 \pm 0.25$ & $49.7 \pm 1.80$ & $640.40 \pm 3.19$ \\
\hline & $T_{3}$ & $8.70 \pm 0.29$ & $0.42 \pm 0.19$ & $1.58 \pm 0.17$ & $99.10 \pm 1.11$ & $4.09 \pm 0.27$ & $59.08 \pm 0.31$ & $1.01 \pm 0.27$ & $53.70 \pm 1.90$ & $644.50 \pm 3.21$ \\
\hline \multirow{4}{*}{$\begin{array}{l}\text { Pomegranate } \\
\text { juice }\end{array}$} & $T_{0}$ & $8.30 \pm 0.20$ & $0.30 \pm 0.15$ & $2.60 \pm 0.13$ & $88.72 \pm 1.01$ & $3.79 \pm 0.23$ & $38 . \pm 0.29$ & $4.26 \pm 0.39$ & $27.41 \pm 0.67$ & $77.50 \pm 0.30$ \\
\hline & $T_{1}$ & $8.33 \pm 0.23$ & $0.33 \pm 0.16$ & $2.66 \pm 0.14$ & $92.02 \pm 1.05$ & $3.92 \pm 0.12$ & $40.01 \pm 0.30$ & $4.38 \pm 0.43$ & $27.45 \pm 0.69$ & $627.50 \pm 3.13$ \\
\hline & $T_{2}$ & $8.35 \pm 0.26$ & $0.35 \pm 0.17$ & $2.68 \pm 0.16$ & $92.54 \pm 0.26$ & $7.78 \pm 0.26$ & $42.09 \pm 0.31$ & $4.43 \pm 0.47$ & $28.41 \pm 0.69$ & $629.5 \pm 3.17$ \\
\hline & $T_{3}$ & $8.38 \pm 0.29$ & $0.37 \pm 0.19$ & $2.70 \pm 0.21$ & $99.10 \pm 1.11$ & $7.81 \pm 0.29$ & $45.02 \pm 0.35$ & $4.49 \pm 0.51$ & $31.86 \pm 0.50$ & $631.50 \pm 3.21$ \\
\hline
\end{tabular}

\section{Conclusion}

From the result it is being concluded that the papaya leaves extract incorporated in Banana shake, Mosambi juice, Pineapple juice, Pomegranate juice of the products were well acceptable on the basis of sensory evaluation. In banana shake Treatment $T_{1}(60: 45: 5)$ was best as compared to other treatments, Treatment $\mathrm{T}_{1}$ (95:5) was best in Mosambi juice followed by $T_{2}$ and $T_{3}$.In pineapple juice $T_{1}$ (95:5) was found to be the best treatments, followed by $T_{1}$ and $T_{3}$. In pomegranate juice $T_{1}(95: 5)$ found to be the best treatment followed by $\mathrm{T}_{2}$ and $\mathrm{T}_{3}$. Banana shake was rich in calcium and protein content .Vitamin $\mathrm{C}$ content was observed high in mosambi juice .Iron content was also rich in pomegranate juice. Total Carotene content was rich in pineapple juice. From the result it can be shows that the addition of papaya leaves extract increased nutrient density of all prepared beverages.

\section{Acknowledgement}

I owe a never ending debt of gratitude to my adored and worshipful God for his grace in the completion of the study. I grateful acknowledge to Dr. Alka Gupta (Advisor) for her great support during my research work.

\section{References}

[1] AOAC, 2007, Official methods of the association of official analytical chemistry, ed. $8^{\text {th }}$.

\section{Volume 6 Issue 7, July 2017 www.ijsr.net}




\section{International Journal of Science and Research (IJSR) \\ ISSN (Online): 2319-7064}

Index Copernicus Value (2015): 78.96 | Impact Factor (2015): 6.391

[2] Baker S S, "The Use and Misuse of Fruit Juice in Pediatrics", Official Journal of American Academy of pediatrics,2000,119 (2): 405.

[3] Coll A J, (Fruit juice consumption by infants and children: a review ,1996,4S-11S.

[4] Gadekar R, "A potential of some medicinal plants as an antiulcer agents", Pharmacogn Rev,2010,136-146.

[5] Ikpeme E V, Ekaluo U B, Kooffreh M E, and Udensi O, Phytochemicals and Heamotological Potential of Ethanol Seed Leaf and Pulp Extract of Carica Papaya(Linn.) Pakistan Jour of biological science, 2011,14(6):L408-411

[6] Imaga $\mathbf{N} \mathbf{A}$, "Phytochemical and antioxidant nutrient constituents of Carica papaya and Parquetina nigrescens extracts" ; Scientific Research and Essays, 2010 (Vol). 5(16). 2201-2205.

[7] Kala P C, "Leaf juice of Carica papaya": A Remedy of Dengue Fever, 2012, 357.

[8] Kamal G Nath , Vijaylakshmi D,.Gowri B S, and Suma $\mathbf{P}$ Utilization of Anne greens for value addition a potential technology for rural women,Banglore.Karnataka Jour.agri.sci, 2005,18(4) (1040-1043).

[9] Nande $\mathbf{P}$, Evaluation of nutritive value and acceptability of recopies prepared from spinach and betel leaves., The Indian jour of nutr.dietet, 2007,44,476.

[10] Otsukia N, Dangb H N, Kumagaia E, Kondoc A, Iwataa S, Morimotoa, D C, Aqueous extract of Carica papaya leaves exhibits anti-tumor activity and immunomodulatory effects Jourl. of Ethnopharmacology,(2009), 760-767.

[11] Pranati D, Premila P, and Gogai M, Nutrient Composition of Some Recipies OF Assam,India, 2009,111-117.

[12] Rangana S , Handbook of Analysis and quality control for fruit and vegetable products, 2001, edi. 2nd.

[13] Redvakaurvakiwww.http://expertscolumn.com/content /15-extra-benefit-papaya-health, 2012

[14] Srilakshmi B, "Food Science" fourth edition. New age International (p) Limited published: New Delhi, 2008, 286-287.

[15] Wexs F, www.http://medic-herbal.blogspot.in papayaleaf-for-health.html, 2013

[16] Wolf A, Bray GA, Popkin BM, A short history of beverages and how our body treats them. Obes Rev, 2008, 9(2):151-64

[17] Zakaria Z A, Jais A M, Sulaiman M R, Mohamed I S S P, Riffin S, "The in vitro Antibacterial of Methanol and Ethanol Extracts of Carica papaya Flowers and Mangiferaindica Leaves", 2006 ,278-283. 